\title{
Międzynarodowe Centrum Badań Wschodnioeuropejskich Uniwersytetu Łódzkiego
}

Międzynarodowe Centrum Badań Wschodnioeuropejskich Uniwersytetu Łódzkiego powstało w roku 2012 z myślą o integracji badań naukowców Uniwersytetu Łódzkiego, a także polskich i zagranicznych wokół rozwiązywania problemów regionu wschodnioeuropejskiego. Europa Wschodnia stanowi znaczący ośrodek oddziaływania politycznego, kulturowo-cywilizacyjnego i gospodarczego. Procesy zachodzące w państwach tego regionu mają i będą miały szczególne znaczenie z punktu widzenia perspektyw rozwoju Polski, a także całej Unii Europejskiej. Centrum tworzą cztery wydziały Uniwersytetu Łódzkiego: Ekonomiczno-Socjologiczny, Filologiczny, Prawa i Administracji, Studiów Międzynarodowych i Politologicznych. Kierownikiem Centrum jest prof. Alicja Stępień-Kuczyńska, sekretarzem - dr Michał Słowikowski.

Do głównych kierunków działalności Centrum należą:

- prowadzenie szeroko zakrojonych badań interdyscyplinarnych o charakterze międzynarodowym i pozyskiwanie grantów na realizację tych przedsięwzięć;

- działania eksperckie realizowane na zamówienie władz regionalnych, organizacji, biznesu;

- prowadzenie działalności wydawniczej i konferencyjnej;

- inicjowanie kształcenia na potrzeby środowisk akademickich i struktur regionalnych;

- aktywizacja środowiska młodych naukowców, doktorantów i studentów w tym obszarze badań;

- gromadzenie zbiorów tematycznych, przygotowanie bibliografii publikacji dotyczących regionu Europy Wschodniej, w tym prac magisterskich, doktorskich i habilitacyjnych;

- wydawanie periodyku: „Eastern Review”.

Centrum Badań Wschodnioeuropejskich Uniwersytetu Łódzkiego współpracuje z następującymi zagranicznymi ośrodkami akademickimi: Białoruskim Uniwersytetem Państwowym w Mińsku (Białoruś), Chmielnickim Uniwersytetem Państwowym (Ukraina), Czerniowieckim Uniwersytetem Państwowym im. Jurija Fedkowycza (Ukraina), Moskiewskim Uniwersytetem Państwowym im. Michaiła Łomonosowa (Rosja), Państwowym Uniwersytetem w Tule (Rosja), Rosyjskim 
Uniwersytetem Przyjaźni Narodów (Rosja), Państwowym Uniwersytetem Społecznym w Moskwie (Rosja), Uniwersytetem Ekonomiczno-Administracyjnym w Pradze (Czechy), Uniwersytetem Lineusza w Växjö (Szwecja), Centrum Badań Wschodnioeuropejskich w Giessen (Niemcy), Uniwersytetem Otto von Guericke w Magdeburgu (Niemcy).

„Eastern Review” jest czasopismem naukowym redagowanym przez Centrum przy współpracy z Komisją Badań nad Integracją Europy Polskiej Akademii Nauk Oddział w Łodzi. Stanowi ono bezpośrednią kontynuację czasopisma o tej samej nazwie ukazującego się w latach 1997-2001, którego założycielem i redaktorem był prof. Jerzy Kmieciński.

Głównym celem redakcji czasopisma jest nie tylko integrowanie wysiłków badawczych naukowców podejmujących w swych pracach problematykę wschodnioeuropejską, ale także popularyzacja wyników ich prac.

Analiza przemian polityczno-prawnych, społeczno-gospodarczych, językowo-kulturowych dokonujących się na Białorusi, w Mołdawii, Rosji i na Ukrainie, pomimo przystąpienia Polski do Unii Europejskiej, nie przestają budzić zainteresowania polskiej opinii publicznej, środowisk akademickich i studenckich, polityków i samorządowców. Przemiany te cechują się znaczną dynamiką i mają wpływ na działalność polskich instytucji państwowych i samorządowych, struktur biznesowych i organizacji pozarządowych.

W periodyku zamieszczane są opracowania politologiczne, prawoznawcze, socjologiczne, ekonomiczne, kulturoznawcze, językoznawcze. Jednocześnie każdy numer czasopisma ma charakter tematyczny. Zamieszczane artykuły ukazują się w języku polskim, rosyjskim, ukraińskim i angielskim.

Międzynarodowy charakter periodyku wynika $\mathrm{z}$ faktu, że w jego prace zaangażowane są białoruskie, rosyjskie, ukraińskie ośrodki akademickie, a także ośrodki naukowe z Czech, Niemiec i Szwecji. Dotychczas Centrum opublikowało następujące numery pisma: Współczesna Ukraina $w$ warunkach nowego tadu międzynarodowego i społeczno-politycznego w regionie Europy Wschodniej, t. 1/2012; Rosja i państwa Europy Środkowej i Wschodniej w obliczu wyzwań modernizacji, t. 2/2013; Polska-Ukraina: Partnerstwo regionów, t. 3/2014. 
EASTERN REVIEW 2015, T. 4

\section{Международный центр по исследованию Восточной Европы Лодзинского университета}

Международный центр по исследованию Восточной Европы Лодзинского университета был создан в 2012 году с целью объединить ученых Лодзинского университета и зарубежных партнеров вокруг решения значимых проблем восточноевропейского региона. Восточная Европа является непосредственно соседствующим регионом и одновременно значимым центром политического, экономического и культурно-цивилизационного влияния. Процессы, протекающие в государствах исследуемого региона, имеют и будут иметь особенное значение для определения вектора развития Польши, а также Европейского Союза. Центр формируют 4 факультета Лодзинского Университета: Экономико-Социологический, Филологический, Факультет Права и Администрации, Факультет Политологии и Международных Отношений. Руководителем центра является профессор Алиция Стемпень-Кучиньска, секретарем - Михал Словиковски.

Направления деятельности Центра:

- проведение обширных интердисциплинарных исследований международного характера, а также изыскание грантов на реализацию этих мероприятий;

- экспертская деятельность, реализуемая по заказу региональных властей, организаций и представителей бизнеса;

- осуществление издательской деятельности и организация конференций;

- инициирование обучения для нужд академических центров и региональных структур;

- активизация сообщества молодых ученых, аспирантов и студентов в этом направлении исследований;

- сбор тематических изданий, подготовка библиографии для публикаций касающихся региона Восточной Европы, в том числе дипломных работ, кандидатских и докторских диссертаций;

- Издание журнала: „Eastern Review”.

Центр По Исследованию Восточной Европы Лодзинского Университета сотрудничает со следующими заграничными академическими центрами: Белорусский Государственный Университет в Минске (Беларусь); Хмельницкий 
государственный университет (Украина); Черновицкий национальный университет имени Ю. Федьковича (Украина); Московский Государственный Университет им. М. Ломоносова (Россия); Государственный Университет в Туле (Россия); Российский Университет Дружбы Народов (Россия); Университет Экономики и Администрации в Праге (Чехия); Университет Линнеус в Векшё (Швеция); Центр исследований Восточной Европы в Гиссен (Германия); Университет им. Отто фон Герике в Магдебурге (Германия).

„Eastern Review” является научным изданием, редактируемым Центром в сотрудничестве с Комиссией исследований европейской интеграции Лодзинского отделения Польской академии наук. Журнал является продолжением одноименного издания, которое выходило в период 1997-2001 гг., основателем и основным редактором которого был профессор Ежи Кмечиньски.

Главной целью журнала является не только объединение усилий исследователей, поднимающих в своих работах восточноевропейскую проблематику, но и популяризация результатов их работы.

Политические, законодательные, общественно-экономические, культурно-лингвистические перемены, происходящие в Беларуси, Молдавии, России и Украине, несмотря на вступление Польши в Европейский союз, не перестают быть объектом внимания польского общественного мнения, академических и образовательных центров, политиков и представителей местного самоуправления. Упомянутые перемены характеризуются значительной динамикой и оказывают влияние на деятельность польских государственных органов и органов местного самоуправления, бизнес-структур и неправительственных организаций.

Круг интересов издания включает в себя страны региона Восточной Европы, рассматриваемой не только в географических категориях, но и в категориях геополитических и общественно-культурных. В связи с этим в центре внимания журнала находятся Беларусь, Россия, Молдавия, Украина и другие страны бывшего СССР.

В журнале публикуются работы политической, законодательной, социологической, экономической, культурологической и лингвистической проблематики. Кроме того, каждый номер издания имеет тематический характер. Статьи в журнале публикуются на польском, русском, украинском и английском языке.

Международный характер издания связан с участием в его работе специалистов из белорусских, российских, украинских, а также чешских, немецких и шведских университетов. До настоящего времени Центром опубликованы следующие номера журнала: Современная Украина в условиях нового международного и общественно-политического порядка в регионе Восточной Европы, т. 1/2012; Россия и страны Центральной и Восточной Европы перед личом модернизачии, т. 2/2013; Польша-Украина: Партнерство регионов, т. $3 / 2014$. 
EASTERN REVIEW 2015, T. 4

\section{International Centre for East European Research University of Lodz}

The idea behind the foundation of the Centre in 2012 was to integrate the research and organizational activity of various units of the University of Łódź - the Faculties of Economics and Sociology; Philology; Law and Administration; and International and Political Studies - pertaining to the, broadly defined, Eastern European studies, and especially focusing on Russia, Ukraine, Belarus and Moldova.

The region of Eastern Europe constitutes, for Poland, its immediate neighbourhood and an important centre of political, cultural, civilizational and economic influence. Social, economic, political and cultural processes taking place in this region's countries will significantly affect Poland's and EU's development.

The activities of the Centre include:

- Broadly conceived interdisciplinary, international research; seeking grants to finance it.

- Expert analyses for local government, organizations and business.

- Publishing and organizing conferences.

- Teaching initiatives for academic institutions and regional structures.

- Encouraging research in the Centre's area of interest among young scholar and $\mathrm{PhD}$ students.

- Gathering thematic library, preparing a bibliography of publications concerning the region of Eastern Europe, including MA, PhD and habiliation dissertations.

- Publishing "Eastern Review" journal, as well as monographs on political, social, economic, historical and cultural issues in Eastern Europe.

At present, ICEER cooperates with the following foreign academic institutions: Belarusian State University, Minsk (Belarus); Khmelnytskyi State University (Ukraine); Jurij Fedkovych State University, Chernivtsi (Ukraine); Mikhail Lomonosov State University, Moscow (Russia); Tula State University (Russia); University of Economics and Administration, Prague (Czech Republic); Linnaeus University, Växjö (Sweden); Centre for Eastern European Research, Giessen (Germany); Otto-von-Guericke University, Magdeburg (Germany). 
"Eastern Review" is a scholarly journal published by ICEER in cooperation with the Committee for the Study of Integration of Europe of the Polish Academy of Science, Łódź division. It is a direct continuation of a journal by the same name published in 1997-2001 by the Centre for the Research and Study of the East (CRSE) of the University of Łódź, whose founder and editor-in-chief was prof. Jerzy Kmieciński.

The aim of ICEER is to integrate scholars of various faculties of the UŁ around the study of Eastern Europe and "Eastern Review" is instrumental in this task. Despite Poland's accession to the EU, political, legal, economic, social and cultural changes that have occurred in Belarus, Ukraine, Moldova and Russia continue to engage Polish public opinion, national and local politicians and the academia. These dynamic transformations have bearing on the activity of Polish national and local government institutions, business organizations and NGOs. "Eastern Review" focuses on Belarus, Moldova, Ukraine and Russia, but also other ex-Soviet countries.

Thematically, "Eastern Review" covers political-legal, social-economic and cultural-linguistic issues. It publishes the work of political scientists, sociologists, legal scholars, economist, linguists and the students of culture. "Eastern Review's" every issue is thematic, with articles in Polish, Russian, Ukrainian and English. The contribution of scholars from a number of academic institutions from Belarus, Czech Republic, Germany, Russia, Sweden, and Ukraine, ensure high quality input by authors from the East Europe region's countries.

So far ICEER has published following volumes of "Eastern Review": vol. 1/2012 (Contemporary Ukraine in front of the new international and socio-political environment in the region of Eastern Europe); vol. 2/2013 (Russia and the countries of Central and Eastern Europe in front of the modernization challenges); vol. 3/2014 (Poland-Ukraine: the Partnership of Regions).

Tłumaczenie Maciej Potz 